\title{
Studying Medicine in Barcelona During the COVID-19 Pandemic
}

Enrique López-Ruiz.'

\section{The Experience}

Here, in Spain, life has rapidly been pushed into an indoor-restricted life as a consequence of the ongoing COVID-19 pandemic. The measures towards an indoor-life started in Barcelona when, on March 12th, the Government of Catalonia published a resolution declaring that presential educational activities must stop.1 Two days later, this resolution was followed by a Royal Decree issued by the Spanish Government, which suspended classes on the whole country and established much more strict measures, such as the obligation to stay at home -with some exceptions, like shopping for groceries or working-.2 Since then, COVID-19 cases have not stopped rising, making Spain the European country with the most confirmed cases, exactly 152,446 on April 9th.3 Because of the strong bond between health institutions and medical training, medicine faculties are being the most affected ones by this worldwide crisis.

\section{What has changed for medical students?}

For me, a second-year medical student at the University of Barcelona, presential classes have not been replaced with recorded or real-time online classes as fast as has been done in other faculties4 -and some classes have not been replaced at all-. Workload has not decreased, and libraries are closed, leaving us without the possibility of consulting a wide range of recommended bibliography. In some subjects, teachers have started uploading their PowerPoint presentations with audio records or explanatory notes, sometimes published with a significant delay. We assume that this lateness on home-learning-appropriate material is due to the fact that our teachers are usually health workers who must be having frenetic and stressful workdays, but this issue is making e-learning harder and slower for students. Moreover, most universities, like the University of Barcelona, have declared the end of presential classes for this semester, 5 what will make us lose face-toface classes even if the lockdown ends before the academic year does. To make everything more complicated, confinement has several negative psychological effects, 6 which we can expect to be influencing our academic performance and that will become worse as the isolation is prolonged.

Even though that every situation that I have described is negative, that is not all the picture. Communication between teachers and students has increased spectacularly and workload is trying to be progressively adjusted. Exams are being rescheduled and the topics that are included in each one are being reevaluated, giving us more time to prepare for them. In addition to this, lots of exams are being planned to be taken online, avoiding a high load of tests when the isolation ends.

A highly relevant concern to take into account is the lack of planned alternatives for clinical practices. On March 9th, all the Catalan medicine faculties cancelled this practices, which are required for the degree.7 I have been lucky enough to be in second year, the last year without clinical practices and, therefore, my knowledge on how it is being managed is very limited, so I will not discuss this topic.

What do we expect for the next weeks of isolation?

It is a common thought between my classmates that the issues previously exposed will eventually disappear. Predictably, communication between teachers and students will continue to increase, and it will help teachers prepare content that is more useful for us. Another important change we will surely experiment is that we will eventually get used to the situation, and thus develop routines and habits that will allow us to decrease isolation-related psychological effects and increase our productivity.

\section{Summary}

The COVID-19 outbreak is the biggest health emergency that Spain has faced since it became a democratic country in the late $70 \mathrm{~s}$ and it is affecting every aspect of its citizens life. For medical students, it is being though to keep up to date with the degree in this new and unexpected situation, but the teaching community is making considerably efforts to make their subjects more accessible.

\footnotetext{
1 Medical Student, University of Barcelona, Spain.
} 


\section{Experience}

\section{References}

1. Departament de Salut de la Generalitat de Catalunya. RESOLUCIÓ SLT/719/2020, de 12 de març, per la qual s'adopten mesures addicionals per a la prevenció i el control de la infecció pel SARS-COV-2 (in Catalan). Available from: https://portaldogc.gencat.cat/utilsEADOP/PDF/8083A/1788965.pdf; cited 2020 April 9.

2. Ministerio de la Presidencia Relaciones con las Cortes y Memoria Democrática. Real Decreto 463/2020, de 14 de marzo, por el que se declara el estado de alarma para la gestión de la situación de crisis sanitaria ocasionada por el COVID-19 (in Spanish). Available from: https://www.boe.es/buscar/doc.php?id=BOE-A-20203692; cited 2020 April 9.

3. Ministerio de Sanidad. Actualizacioń no 70. Enfermedad por el coronavirus (COVID-19) (in Spanish). Available from: https://www.mscbs.gob.es/profesionales/saludPublica/ccayes/alertasActual/nC ov-China/documentos/Actualizacion_70_COVID-19.pdf; cited 2020 April 9.

4. Biavardi NG. Being an Italian medical student during the Covid-19 outbreak. Int J Med Students. 2020 Apr;8(1):49-50
5. Universitat de Barcelona. RESOLUCIÓ del rector de la Universitat de Barcelona de cessament de la docència presencial corresponent al segon quadrimestre del curs acadèmic 2019-2020 (in Catalan). Available from: https://seu.ub.edu/documentPublic/download/134397; cited 2020 April 9.

6. Brooks SK, Webster RK, Smith LE, Woodland L, Wessely S, Greenberg N, et al. The psychological impact of quarantine and how to reduce it: rapid review of the evidence. Lancet. 2020 Mar 14;395(10227):912-20.

7. Universitat de Barcelona; Universitat de Girona; Universitat de Lleida; Universitat Autònoma de Barcelona; Universitat de Vic; Universitat Rovira i Virgili; Universitat Pompeu Fabra; Universitat Internacional de Catalunya. Comunicat de les deganes i degans de les facultats de medicina i ciències de la salut de Catalunya en relació a la situació epidèmica per COVID-19 i les pràctiques clíniques de l'alumnat de diferents graus (in Catalan). Available from: https://www.ub.edu/portal/documents/4493882/6374423/Comunicat+Suspensio + Practiques; cited 2020 April 9.

\section{Acknowledgments \\ None}

Conflict of Interest Statement at Funding

The Authors have no funding, financial relationships or conflicts of interest to disclose.

Author Contributions

Writing - Original Draft: ELR.

Cite as:

López-Ruiz E. Studying Medicine in Barcelona During the COVID-19 Pandemic. Int J Med Students. 2020 Jan-Apr;8(1):60-61.

This work is licensed under a Creative Commons Attribution 4.0 International License

ISSN 2076-6327

This journal is published by the University Library System, University of Pittsburgh as part of the Digital Publishing Program and is co-sponsored by the University of Pittsburgh Press. 